\title{
Origin and deformation of intra-salt sulphate layers: an example from the Dutch Zechstein (Late Permian)
}

\author{
B. C. Biehl*, L. Reuning, F. Strozyk, and P. A. Kukla \\ EMR - Energy and Mineral Resources Group, Institute of Geology and Palaeontology, \\ RWTH Aachen University, Wuellnerstraße 2, 52056 Aachen, Germany \\ *Corresponding author (e-mail: bianca.biehl@emr.rwth-aachen.de) \\ The final publication is available at springer via \\ http://dx.doi.org/10.1007/s00531-014-0999-4
}

\begin{abstract}
From salt mine galleries and well data it is known that thick rock salt layers can contain anhydrite and carbonate layers with thicknesses on the millimetre to tens of metre scale. The relatively thick Zechstein 3 (Z3) anhydrite-carbonate layer in the northern Netherlands has been studied previously using 3D seismic data. Observations from geophysical well logs in this study reveal the presence of thin sulphate layers on the sub-seismic scale imbedded in the Zechstein 2 (Z2) salt. Core samples, thin sections, seismic data, and geochemical measurements were used to determine the mineralogy and origin of one of these Z2 sulphate layers. Bromine analyses show that they mark a freshening event in the Z2 salt, which can be correlated over large distances in the northern Netherlands. Their corecalibrated log signature indicates that the Z2 sulphate layers consist either of pure anhydrite or of anhydrite and polyhalite. The mineralogy and thickness of the sulphate layers is interpreted to vary between synsedimentary morphologic lows (thin anhydrite-polyhalite couplets) and highs (thicker anhydrite layers). Such a combination of core observations and well log analysis is a powerful tool to detect lateral trends in evaporite mineralogy and to reconstruct the environmental setting of their formation. Salt internal geometries can further be used to distinguish between different deformation mechanisms. In our study area the distribution of sulphate layers within the Zechstein 2 salt indicates that subjacent salt dissolution was not the dominant process leading to salt-related deformation.
\end{abstract}

Keywords: evaporite, polyhalite, anhydrite, bromine geochemistry, Southern Permian Basin, salt tectonics 


\section{Introduction}

Evaporitic and carbonate layers and bodies imbedded in rock salt can be of broad economic interest as they may constitute valuable hydrocarbon reservoirs (Schoenherr et al. 2009), but may also impose potential drilling risks due to their high fluid overpressures (Williamson et al. 1997, Kukla et al. 2011). Intra-salt deformation structures were previously studied based on seismic data from e.g. the Brazilian offshore (Fiduk and Rowan 2012), based on field work in surface piercing salt domes in Oman (Reuning et al. 2009), and within mining galleries in structural shallow levels of various salt diapirs (Geluk 1995, Behlau and Mingerzahn 2001). The above studies have demonstrated that analysing intra-salt geometries leads to an increased understanding of internal deformation mechanisms in salt diapirs.

Methods to visualize and predict such intra-salt lithologies have benefited from the improvements in sub-salt imaging over the last couple of years (Leveille et al. 2011). In that context, developments in seismic acquisition (Vigh et al. 2011), processing (Wang et al. 2008) and imaging (Ji et al. 2011) have been made and bear significant importance for intra-salt imaging (Ji et al. 2011), finding means to better explain the heterogeneity of intra-salt structures. In the northern Netherlands, the collection of wide azimuth data for example now allows a 3-D view of large-scale geometries of the intra-salt Zechstein 3 anhydrite-carbonate layer (Z3 stringer) with a resolution of tens of metres (van Gent et al. 2011, Strozyk et al. 2012). However, from salt mine galleries and well data it is well known that the rheological heterogeneity of layered evaporites is much higher than imaged in seismic data. This is because of the large variability in the composition and thicknesses of anhydrite and carbonate layers ranging from millimetre to metre scale. Few attempts have been made to model the dynamics of such solid inclusions within salt (Weinberg 1993, Koyi 2001, Chemia et al. 2008, Burchardt et al. 2011, Burchardt et al. 2012, Li et al. 2012a). It has been postulated that these stringers were being passively dragged within the salt during flow (Koyi 2001) and that they therefore could be used as tracers of salt deformation mechanisms. Both, the processes and mechanisms of the development of such intra-salt layers as well as their role for the rheological and mechanical heterogeneity of salt layers during halokinesis are still poorly understood. This is partly because of the simplistic approach used in numerical models, which often need to assign homogeneous material properties to salt, anhydrite and carbonates.

The Zechstein 2 (Z2) Salt Member is the thickest salt unit onshore the northern Netherlands. At least two prominent, 0.3 - $2 \mathrm{~m}$ thick intra-Z2 sulphate layers exist, which can be detected on well logs in different parts of the basin based on their characteristic log signature of high gamma ray and density values. The basin-wide distribution of these sulphate layers is challenging to predict since they are not resolved in seismic data. Our study aims to analyse the internal geometries of the thick Z2 salt interval on the sub-seismic scale and to understand the genesis of the Z2 intra-salt sulphate layers using an integrated approach. Therefore, we utilize a dense grid of well log data and calibrate the log signature with analyses of the mineralogy and geochemistry of core sections, using thin-section petrography, x-ray diffraction, x-ray fluorescence, and ion chromatography. Finally, a combination of seismic and well log data is used to evaluate the role of subjacent evaporite dissolution on salt related deformation processes. This demonstrates exemplarily that internal geometries within salt structures provide information about deformation processes that cannot be obtained based solely on their external shape. 


\section{Geological setting}

The study area is located in the western part of the Southern Permian Basin (SPB). The land-locked depression developed due to high subsidence rates and underwent several flooding periods in Late Permian (Zechstein) times (Pharaoh et al. 2010). The evaporite sedimentation began when the dry basins where flooded from the Boreal Sea in the north by a combination of rifting and a rise in sea-level. Thick rock salt series occupied the basin centre, with anhydrites and carbonates depositing at the basin margins and onlapping onto isolated structural highs (Taylor 1998). Cyclical sea-level fluctuations controlled sedimentation patterns in the SPB during the Zechstein. In total, 5-7 carbonate-evaporate cycles were classified for the SPB, whereof each transgression phase marks the base of a new cycle (Peryt et al. 2010). In the Netherlands, the Zechstein Group comprises five evaporite cycles (Z1 - Z5) of formation rank (Fig. 1). All cycles were described in detail by van Adrichem Boogaert and Burgers (1983), Taylor (1998), Geluk (2000, 2007), and Geluk et al. (2007). Normal marine seawater conditions prevailed during the deposition of the lower Zechstein cycles (Z1-Z3). Carbonates and evaporites were deposited as series of prograding and aggrading sigmoidal shaped bodies, while clastic sedimentation was limited to the basin margin. Hypersaline conditions prevailed during the formation of higher cycles under playa conditions (Geluk 2007), leading to a deposition of anhydrites and halites instead of carbonates. The focus of this study is the Zechstein 2 Salt Member, which has a today's thickness of over $600 \mathrm{~m}$ in the basin centre and shows a halite content of $>95 \%$. Therefore, it forms the thickest rock salt deposit in the Netherlands. Two thin layers of presumed polyhalite, a hydrated sulphate of magnesium, calcium and potassium $\left(\mathrm{K}_{2} \mathrm{Ca}_{2} \mathrm{Mg}\left(\mathrm{SO}_{4}\right)_{4} \cdot 2 \mathrm{H}_{2} \mathrm{O}\right)$, are present inside the salt body (Geluk 1995), which are the focus of this study and separate the Z2 salt into three sub-members: the Lower Salt, the Middle Salt, and the Upper Salt (RGD 1991). The present-day thickness of each member is variable due to erosion and post-Permian salt movement and cannot be considered as the original thickness at the time of deposition (Taylor 1998). Salt movement highly affected the SPB area and is a major factor controlling sedimentation and the trapping of hydrocarbons (Kukla et al. 2008). The $\mathrm{Z} 2$ salt forms the most mobile salt unit in the Zechstein and affects the overlying layers, especially the Z3 stringer, which was strongly folded by the movement and suffered locally from boudinage (Strozyk et al. 2012). Small scale salt movement started in the Early Triassic, due to extensional tectonics (Geluk 2007), continued on a large scale in Late Cretaceous times, when compressive stresses laterally squeezed and deformed large parts of the Zechstein (Mohr et al. 2005, Geluk 2007), and in the Cenozoic when inversion tectonics reactivated the salt movement (Mohr et al. 2005, Geluk et al. 2007).

\section{Material and Methods}

24 core samples of wells Barradeel Salt 01 (BAS-01) and Pieterburen 01 (PBN-01) were collected in the core ware house of the Netherlands Organisation for Applied Scientific Research (TNO), Utrecht-Zeist, the Netherlands. Both wells are located onshore in the northwest Netherlands. Structurally, BAS-01 belongs to the westernmost Friesland Platform, while PBN-01 is positioned at the NW edge of the Groningen field (Fig. 1). Both core intervals showed the upper metres of the Zechstein 2 Salt Member including one Z2 sulphate layer, which we named Z2sl2. All samples were measured by x-ray diffraction (XRD) with a Siemens D 5000 diffractometer. The software Eva 8.0 was used to identify the mineral phases and Topas 2.0 for the 
accompanying Rietveld analysis, which was used to quantify the proved mineral phases. The measurements were made over an angle field of $60^{\circ}\left(3^{\circ}-63^{\circ}\right)$ with an angle step of $0.02^{\circ}$ per second. The calculated error for the Rietveld analysis is less than $1.5 \%$.

Eight salt samples of well PBN-01 and nine salt samples of well BAS-01 were measured by ion chromatography in order to quantify the potassium, calcium and magnesium concentrations. In addition, the bromine contents of all salt samples have been measured to determine the degree of evaporation of the parental fluids that led to the precipitation of the Zechstein 2 Salt Member. These measurements were performed at the Institute of Clay and Interface Mineralogy (CIM), RWTH Aachen. All samples were pulverised with a laboratory disc mill and 350 $\mathrm{mg}$ of each sample were dissolved in $250 \mathrm{~mL}$ distilled water. Aliquot samples were taken for cation and anion analysis. The ions were detected by using special cation and anion eluents. In this case, the cation eluent consisted of nitric acid and dipicolinic acid while the anion eluent was made of sodium bicarbonate and sodium carbonate. Non-soluble residues are not measured by ion chromatography. The internal precession of the measurements ranges between $0.8 \%$ and $1.3 \%$ (1 standard deviation; 1SD).

A handheld gamma-ray and an x-ray fluorescence (XRF) measurement device were applied directly on the core samples of well BAS-01 in the core repository. Potassium, uranium and thorium were measured with the spectral gamma ray equipment, while the XRF analysed all ion concentrations of atomic numbers ranging from potassium to antimony. Based on duplicate measurements, the internal precession (1SD) of the XRF results is \pm $0.4 \%$ for calcium and $\pm 1 \%$ for potassium.

Transmitted light microscopy was performed on one thin section of the Z2sl2 layer of each well.

A modern 3-D seismic dataset from the northern Netherlands was provided by the Nederlandse Aardolie Maatschappij BV Assen (NAM) for the study. The seismic to simulation software Petrel 2010 by Schlumberger was used for the interpretation. Gamma ray-, sonic-, and density-logs were included in the project for a high number of wells drilled in the Netherlands. These logs were used for the identification of the stratigraphic Zechstein cycles, and served as input for 3-D subsurface models, in which gridded well tops were used to create an isopach (thickness) map and a density distribution map of the Z2sl2 layer.

\section{Results}

\section{Core description}

The very well preserved core section of well BAS-01 consists of parts of the upper Zechstein 2 Salt Member and a $0.7 \mathrm{~m}$ thick Z2sl2 layer (2677.05 m to $2677.75 \mathrm{~m}$ ). Above this layer, several thin (ca. 1 - $10 \mathrm{~mm}$ ) anhydrite layers are intercalated within the salt (Fig. 2-A). These layers separate layers of very large, translucent halite crystals (up to $5 \mathrm{~cm}$ in size; Fig. 2-B) from very fine halite crystals. The halite crystal size varies strongly within each individual salt layer but does not necessarily scale to the layer's thickness. Many halite crystal boundaries can also be seen along the anhydrite layer's surfaces, as well as some open pores in the shape of euhedral halite crystals along the core's sidewalls (Fig.2-A). The Z2sl2 has a light grey colour, and a massive to partly laminated fabric (Fig. 3-A). The dark laminae have a thickness less than $2 \mathrm{~mm}$ and decrease in abundance with depth, where they occur in intervals of $1-2 \mathrm{~cm}$. In contrast, the top of the Z2sl2 shows lamination intervals $<5$ $\mathrm{mm}$. 
The salt interval underlying the Z2sl2 appears in a different texture than the salt above the sulphate layer. Here, the anhedral halite is much finer grained (up to $1 \mathrm{~cm}$ in size) and does not show large variations in crystal size. Additionally, the salt shows a slightly red colour, probably due to iron-bearing mineral inclusions.

The core section of well PBN-01 (834.4 m - $835.7 \mathrm{~m}$ ) includes the Zechstein 2 salt, and an intercalated $0.3 \mathrm{~m}$ thick dark grey evaporitic layer (Z2sl2), which separates the Zechstein 2 Salt Member in two sections (Middle Salt and Upper Salt) at $835.01 \mathrm{~m}$ depth. The Zechstein 2 Salt Member consists of nearly pure halite (> $95 \%$ $\mathrm{NaCl}$ ) without any remarkable structures, like a large grain size or a separation by thin anhydrite layers, as seen before in BAS-01. A massive non-laminated texture is present at the top part of the Z2sl2 interval (Fig. 3-B), while a more laminated texture is found at the bottom. Several pores plugged with halite are present in the Z2sl2 layer.

\section{Geochemistry}

$\underline{B A S-01}$

Four Z2sl2 samples of well BAS-01 were analysed with x-ray diffraction (XRD), and nine rock salt samples of the surrounding Zechstein 2 Salt Member were analysed with XRD and ion chromatography. Additionally, several x-ray fluorescence analyses (XRF) were applied directly on the core section in the core repository. The results of the geochemical analyses are displayed in Table 1 and Figure 4-A. The rock salt samples taken from below the Z2sl2 contain halite (77 - 87 \%) with higher amounts of polyhalite (11 - $21 \%$ ) and some dolomite (< $3 \%$ ). Due to the high amounts of polyhalite in this salt interval, potassium concentrations of up to $8 \% \mathrm{~K}^{+}$were detected by XRF (Fig. 4-A). In addition, a slightly higher gamma ray signal and therefore a higher natural radioactivity for the salt below the Z2sl2 is shown on the well log (Fig. 5-A). This effect can be explained by the presence of polyhalite in the salt samples. The results of the ion chromatography measurements show high $\mathrm{Ca}^{2+}$, $\mathrm{Mg}^{2+}$-, and Br-concentrations for the lower salt interval. The bromine concentration ranges between $341 \mathrm{ppm}$ and $381 \mathrm{ppm}$ in this lower salt interval (Fig. 4-A), while $\mathrm{Ca}^{2+}$-concentrations up to $1.8 \%$ and $\mathrm{Mg}^{2+}$ concentrations up to $0.8 \%$ are reached (Table 1 ).

The Z2sl2 itself can be subdivided into two sections. The lower part consists of pure polyhalite $\left(\mathrm{K}_{2} \mathrm{Ca}_{2} \mathrm{Mg}\left(\mathrm{SO}_{4}\right)_{4}\right.$ - $\left.2 \mathrm{H}_{2} \mathrm{O}\right)$ with some anhydrite $\left(\mathrm{CaSO}_{4}\right)$ in one sample. The upper part, however, is composed of $100 \%$ anhydrite. A high gamma ray signal can be seen on the well log of BAS-01 for the depth of the Z2sl2 (Fig. 5-A). The results of the handheld gamma ray equipment prove potassium as the present radioactive phase. Concentrations up to $8 \% \mathrm{~K}^{+}$were measured by XRF for the Z2sl2 in a depth of $2677.5 \mathrm{~m}$ (Fig. 4-A). It is likely that the potassium-bearing polyhalite is the reason for the clear gamma ray signal. Within an interval of $8 \mathrm{~cm}$ around a depth of $2677.35 \mathrm{~m}$, the potassium concentration increases down-core from $0.3 \%$ to $5.5 \% \mathrm{~K}^{+}$, while the calcium content decreases down-core from over $20 \%$ to $9 \% \mathrm{Ca}^{2+}$, indicating the transition from $\mathrm{K}^{+}$-bearing polyhalite to anhydrite (Fig. 4-A).

The salt interval above the Z2sl2 shows a different mineralogy than the lower salt interval. The salt samples consist of $>98 \%$ halite with some traces of anhydrite. No polyhalite was detected here and a decreased gamma ray signal is present on the well log compared to the depth of the lower salt interval (Fig. 5-A). Additionally, lower potassium concentrations $\left(<2 \% \mathrm{~K}^{+}\right)$were measured by XRF for the upper salt interval. The results of the ion chromatography show significantly lower concentrations of $\mathrm{Ca}^{2+}, \mathrm{Mg}^{2+}$ and $\mathrm{Br}$ for this salt interval. The 
bromine profile line (Fig. 4-A) here ranges between $288 \mathrm{ppm}$ and $310 \mathrm{ppm}$, while the $\mathrm{Ca}^{2+}$ - and $\mathrm{Mg}^{2+}-$ concentrations vary between 200 and 500 ppm (Table 1).

\section{$\underline{P B N-01}$}

Eight salt samples and three Z2sl2 samples of well PBN-01 were first analysed with x-ray diffraction and ion chromatography. The salt samples below the Z2sl2 consist of over $98 \%$ halite and some anhydrite. The measured bromine values are considerably lower than the ones from BAS-01 and range from 130 ppm to 189 ppm (Table 1). The bromine profile line (Fig. 4-B) shows a slight decrease of the $\mathrm{Br}$ concentration up-core towards the Z2sl2. Slightly higher radioactivity values were recorded on the gamma ray log for this lower salt interval (Fig. 5-B).

The Z2sl2 consists of over $86 \%$ anhydrite, up to $12 \%$ magnesite and some halite. The well log (Fig. 5-B) shows a high gamma ray signal in this depth. However, the XRD measurements do not indicate polyhalite or other potassium bearing minerals (Table 1 ).

The salt samples above the Z2sl2 consist of $>99 \%$ halite with some traces of anhydrite (Table 1). The ion chromatography results show the lowest Br values right above the Z2sl2 (sample PBN-01G) and then a gradual increase in $\mathrm{Br}, \mathrm{Mg}^{2+}$, and $\mathrm{Ca}^{2+}$-concentrations towards the top part of the studied halite interval (Table 1; Fig. 5B).

\section{Well log analysis}

Using geophysical well logs, the Z2 sulphate layers are detected as peaks in gamma ray, sonic and density logs relative to the surrounding halite. Thereby, the density log enables to distinguish between anhydrite and polyhalite. 139 density logs from Z2-penetrating onshore wells have been studied regarding their density value at the level of the Z2sl2 layer. 94 wells show maximum bulk densities $>2.8 \mathrm{~g} / \mathrm{cm}^{3}$, 30 of these show values $>2.9$ $\mathrm{g} / \mathrm{cm}^{3}$, with a maximum of $3.01 \mathrm{~g} / \mathrm{cm}^{3}$. With these results a density distribution map has been created (Fig. 6-A), which shows that the highest density values are located in the area of Groningen and that lower density values, ranging from $2.5 \mathrm{~g} / \mathrm{cm}^{3}$ to $2.7 \mathrm{~g} / \mathrm{cm}^{3}$, are found westwards in the Lauwerszee Trough (cf. Fig. 1) and along the north-western coastal area, especially around Ameland. In addition, a thickness map (Fig. 6-B) has been calculated using the well log information. The map shows that the highest thicknesses (up to $2 \mathrm{~m}$ ) of the Z2sl2 can be found on and along the Groningen High, whereas minor thicknesses $(0.4 \mathrm{~m}-1 \mathrm{~m})$ are present in the area of the Lauwerszee Trough.

\section{Thin section microscopy}

The thin section of the BAS-01 Z2sl2 shows a fine-grained, greyish matrix of granular polyhalite with isolated coarser grained crystals in between (Fig. 8-A). Under crossed polars the polyhalite crystals show low interference colours up to low second order and especially the coarser crystals show a distinctive simple twinning (Fig. 8-B), which is typical for polyhalite (Adams et al. 1984). No other mineral inclusions or replacement structures are present in this section.

Anhydrite crystals dominate the sample of PBN-01 with a few visible halite cements inside vugs (Fig. 8-C). The anhydrite crystals are arranged in radial-fibrous aggregates or parallel-fibrous structures (Fig. 8-D). No replacement structures are visible. 


\section{Discussion}

The two Z2 sulphate layers were identified on geophysical well logs for all wells onshore the northern Netherlands. These layers divide the Zechstein 2 Salt Member into three stratigraphic salt sections (RGD 1991), and can be used as basin-wide marker horizons. Thus, we concur with Geluk (1995) that the Z2 sulphate layers occur on a regional scale, which has been previously questioned by Borchert and Muir (1964). The density and gamma ray well log information can be used to determine the mineralogy of the upper Z2 sulphate layer (Z2sl2). On geophysical well logs, anhydrite typically has a density of $2.98 \mathrm{~g} / \mathrm{cm}^{3}$ and an average natural radioactivity of around 10 API units, whereas polyhalite has a density of $2.79 \mathrm{~g} / \mathrm{cm}^{3}$ and a natural radioactivity of 190 API units (Rider and Kennedy 2011). Density values $>2.8 \mathrm{~g} / \mathrm{cm}^{3}$ are too high to represent an occurrence of pure polyhalite. As shown for well BAS-01 (cp. Fig. 3-A), we assume that interlayered polyhalite and anhydrite cause high values in density logs, as well as clear signals in the gamma ray logs, and that anhydrite and polyhalite are both present in the Z2 sulphate layers in variable proportions. Fig. 7 exemplarily shows four wells, named A - D, and their density and gamma ray log information at the depth level of the Z2sl2 layer. The Z2sl2 of each well shows different maximum density values, ranging from $2.51 \mathrm{~g} / \mathrm{cm}^{3}$ (well A) to $2.96 \mathrm{~g} / \mathrm{cm}^{3}$ (well D). The density values are highest in the area of the Groningen High (Fig. 6-A). At well D (Fig. 7), the lack of a gamma-ray peak associated with a very high density for the Z2sl2 indicates that anhydrite is the predominant mineral phase. In areas beyond the Groningen High the density ranges between typical polyhalite and anhydrite values (Fig. 6-A). Typical well log signatures for these areas either show a co-occurrence of polyhalite and anhydrite or an alternation of a density maximum at the top and a gamma-ray maximum at the base of the Z2sl2 (Fig. 7, well C). Such an alternation indicates that these sulphate layers are dominated by anhydrite in their upper part and polyhalite in their lower part, as also observed on core BAS-01. In contrast, a co-occurrence with a slight offset of the density and gamma-ray peaks (Fig.7, wells A and B) with density maxima $<2.8 \mathrm{~g} / \mathrm{cm}^{3}$ rather point to a clear predominance of polyhalite. Areas that are characterized by maximum well log densities below typical polyhalite values normally show also reduced gamma-ray values (Fig.7, well A). Here, we have to take into account that a thickness below the vertical resolution of the logging tool will reduce the amplitudes of the log signals. According to Rider and Kennedy (2011), the true gamma-ray and density amplitudes will be measured when the layer of interest has a minimum thickness of $50 \mathrm{~cm}$. Since the thickness of the Z2sl2 - measured at the full width at half maximum of the signal peak - is around $50 \mathrm{~cm}$ in well A, the well log signal might still be reduced. In summary, the logging data show that anhydrite is the dominant mineralogy along structural highs such as the Groningen High, whereas a combination of anhydrite and polyhalite in variable proportions is present in other parts of the basin. This also concurs with the results of the Z2sl2 thickness map shown in Figure 6-B. The highest thicknesses are found on the Groningen High and coincide with the presence of anhydrite as predominant mineral phase (Fig. 6-A). In contrast, thinner Z2sl2 intervals occur in areas where polyhalite is prevalent.

In order to determine the composition of the marine parental brine that led to the formation of the $\mathrm{Z} 2$ sulphate layers and the precipitation of the $\mathrm{Z} 2$ salt, bromine concentrations can be used. Bromine is the fourth most abundant anion in seawater after $\mathrm{Cl}^{-}, \mathrm{SO}_{4}{ }^{2-}$ and $\mathrm{HCO}_{3}{ }^{-}$(Warren 2006). Although $\mathrm{Br}$ can substitute for chlorine in a halite lattice due to a similar ionic radius, it preferentially remains in solution. This leads to an enrichment of bromine in the parent fluid during evaporation before getting integrated in precipitated halite (Braitsch 1971). An increase in the Br-concentration of the parent brine leads to an increase of $\mathrm{Br}$ in halite crystals, respectively. 
Rock salts precipitated from Permian seawater, which is comparable to modern seawater (Harvie et al. 1980), show $\mathrm{Br}$ concentrations of around 75 ppm (Bornemann et al. 2008). Figures 4-A and B show decreasing bromine values up-core towards the Z2sl2 layer, whether consisting of anhydrite or polyhalite, likely indicating a freshening event that can be correlated throughout the entire basin facies in the study area. This freshening culminated in the precipitation of sulphate when the brine concentration fell below halite saturation. Although the trends in Br-concentrations are similar in both cores, the absolute values are much higher in well BAS-01 where polyhalite is the dominant sulphate phase. The higher Br-concentrations and the occurrence of K-Mg-salts right below the Z3 stringer (Fig. 5-A) show that well BAS-01 was located in a more restricted part of the basin compared to the anhydrite dominated core of well PBN-01, which was situated in the vicinity of the Groningen High. Br-concentrations comparable with our study were also observed from the Zechstein 2 salt interval of the Gorleben Salt Dome, Germany, and increased Br-concentrations were also correlated with the occurrence of polyhalite (Bornemann et al. 2008). A close tie between bromine values measured in rock salt and interbedded sulphate layers was already recorded by Peryt et al. (2005). They showed that the bromine distribution in the platform and slope facies of the Werra Halite (Z1) in Poland indicated fluctuation of the brine composition during halite deposition. Rapid decreases of bromine commonly coincided with the occurrence of thin anhydrite intercalations, which is also the case for the Z2 salt basin facies in our study area. In some rare cases, polyhalite was present instead of anhydrite and Peryt et al. (2005) concluded that the polyhalite was preceded by the syndepositional anhydritisation of a gypsum deposit, and that the resulting anhydrite was then transformed to polyhalite by reacting with highly evolved marine brines. A comparable approach was already made by Harvie et al. (1980) who stated that the formation of polyhalite is a possible back-reaction of the solution with earlyformed anhydrite or gypsum. However, polyhalite can also be of primary origin. Primary polyhalite textures were formerly described by Steward (1963) and Colter and Reed (1980) for the Zechstein 2 basin evaporites of NE England. The latter interpreted a fine-grained polyhalite texture with some coarser crystals, as seen in our sample of BAS-01, to be of primary origin. In addition, the co-occurrence of polyhalite and halite precipitation in high temperature settings $\left(>30^{\circ} \mathrm{C}\right)$ was also reported from Spain (Peryt et al. 2005). Since there is no petrographic evidence for a replacement of anhydrite by secondary polyhalite (Fig. 8), we assume that the polyhalite within the Z2 sulphate layers is of primary origin. Core and well log analysis of well PBN-01 (cp. Fig. 7, well C) showed that anhydrite occurs on top of polyhalite and therefore, downward migrating fluids cannot be the reason for the presence of polyhalite. Hence, a freshening of seawater is the best explanation for a sudden precipitation of anhydrite instead of polyhalite, as also stated by Colter and Reed (1980) for their study area in NE England. Based on our observations on core samples, geochemistry results (Table 1), and the density distribution map (Fig. 6-A) a conceptual model for the formation of the Z2 sulphate layers is presented in Figure 9. We propose that polyhalite was precipitated after halite from $\mathrm{K}^{+}$- and $\mathrm{Mg}^{2+}$ - rich brines in the area of the Lauwerszee Trough and the Friesland Platform during the initial stage of freshening. At this time, the Groningen High was likely elevated above the brine level and therefore devoid of from polyhalite precipitation (Fig. 9-A). A further freshening of seawater caused a brine level rise and led to the precipitation of Ca-sulphate on top of polyhalite in morphologic lows, and the first Ca-sulphate precipitation along the Groningen High (Fig. 9-B). Initially, the Ca-sulphate was likely deposited as gypsum and later replaced by anhydrite, as indicated by the radial-fibrous aggregates observed in well PBN-01 (Fig. 8-D). These structures are commonly interpreted as pseudomorphs of anhydrite after gypsum (Bäuerle et al. 2000). Since halite is known to precipitate from a water column of less than $2 \mathrm{~m}$ (Warren 1982) and gypsum in water depth of $<10 \mathrm{~m}$ (Logan 1987), the inferred 
contrast in elevation could be on a meter scale. This leads to the general implication that changes in mineralogy of evaporitic layers are detected on well logs and may serve as indicators of subtle differences in elevation between morphologic highs and lows within salt basins. Such a morphologic differentiation of the basin during Zechstein times is consistent with off-platform highs in the Groningen area (Fig. 6-A) during the Z3 carbonate cycle (Geluk 2000). In our case the presence of anhydrite coincides with a structural high, possibly indicating synsedimentary tectonic activity, synsedimentary salt deformation, or evaporite precipitation on a predefined relief.

Compared to the clear visibility of the Z2 sulphate layers in density, gamma ray and sonic logs, they are invisible in the seismic image due to a limited resolution of the seismic data, although the transition from halite to anhydrite or polyhalite and vice versa should produce high acoustic impedance contrasts. Given the fact that the seismic data used has a good quality and that the $\mathrm{Z} 2$ salt is buried to a medium depth, a formation thickness of at least 2 - $5 \mathrm{~m}$ is required to detect layers like the Z2sl2 in the seismic (Brown 1999). Layer thicknesses of the Z2sl2 between $0.3 \mathrm{~m}$ and $2 \mathrm{~m}$ in this study are well below this threshold (Fig. 4). Instead, geophysical well log signatures can be used for the interpretation of internal salt geometries that cannot be recognized in seismic data. This is important since the external shape of salt structures does not necessarily reflect their internal deformation processes and resulting shapes as has been shown e.g. for the Santos Basin offshore Brazil (Fiduk and Rowan 2012). Cartwright et al. (2001) proposed that commonly observed stratal geometries on the flanks of salt structures can be explained alternatively by passive down-building or subjacent salt dissolution. During passive down-building, the salt structure would rise in response to regional subsidence and sediment loading adjacent to the structure. In this model, the final top salt surface at the crest of the salt structure would be above its initial position. In contrast, subjacent dissolution could be caused by undersaturated fluids circulating along the base of the salt body (Fig. 10). This would lead to a localized depletion of salt at the base of the evaporite sequence, creating accommodation space at the top salt surface that is rapidly filled by sedimentation. In this model, the final top salt surface would be close to its initial position at the crest and below the initial position underneath the sediment-filled mini-basins at the flanks of the salt structure (Fig. 10). Both mechanisms could result in very similarly shaped salt structures, which would be difficult to distinguish based on their external geometry (Cartwright, 2001). However, the log based interpretation of their internal geometry can help to evaluate the influence of subjacent salt dissolution. In an end-member scenario for subjacent salt dissolution, the salt should have been removed preferentially from the lower salt unit below the mini-basin, which would have been in direct contact with the undersaturated water. To test this hypothesis, we used two wells for a salt structure within our study area (Fig. 11). One well is located close to the centre of the adjacent mini-basin (well A), whereas the other one is situated close to the crest of the salt structure (well B). The Z2 sulphate layers Z2sl1 and Z2sl2 separate the Z2 salt in three sections: the Lower Salt (LS), the Middle Salt (MS), and the Upper Salt (US). Since subjacent dissolution is removing salt only at the base of the salt unit, the lowermost salt unit will dissolve whereas the higher salt units will show a nearly constant thickness. Less soluble interlayers within the dissolved salt will finally form a dissolution breccia at the base of the salt unit. Figure 11 shows that at well A, the thickness of the total Z2 layer is reduced by $60 \%$ compared to well B. The Lower, Middle and Upper Salt units at well $\mathrm{A}$ are reduced by $63 \%, 60 \%$ and $45 \%$, respectively. The fact that all three stratigraphic salt packages beneath the mini-basin lost a significant salt volume indicates that passive down-building rather than subjacent salt dissolution was the dominant process of salt-related deformation in the study area. However, an additional modification by salt dissolution cannot be ruled out completely. The minor thickness reduction of the upper salt 
layer compared to the lower ones is consistent with a lower velocity of the salt flow within a relatively thin salt layer wedged between two brittle layers as shown by numerical finite element modelling (Li et al., 2010). This observation is also in accordance with the idea that the internal deformation of salt bodies is among other factors controlled by the number, thickness and rheology of interlayered evaporites (e.g. anhydrite, polyhalite) that are mechanically stronger than the surrounding rock salt. This is also shown by analogue modelling experiments (Zulauf et al., 2009) and numerical finite element modelling (Li et al., 2012a; Li et al., 2012b) The analysis of core calibrated geophysical log signatures is a powerful tool to map such internal heterogeneities in salt bodies with a sub-seismic resolution and can therefore help to fill the information gaps the seismic leaves behind.

\section{Conclusions}

- Core-calibrated geophysical logging data can be used to map spatial trends in evaporite mineralogy that can be related to the degree of basin restriction and/or palaeomorphology of the evaporite basin. Two thin, intrasalt Zechstein 2 sulphate layers that consist of variable proportions of the sulphates anhydrite and polyhalite are identified on geophysical well logs onshore the northern Netherlands, dividing the salt sequence into three stratigraphic sections: the Lower Salt, Middle Salt, and Upper Salt.

- The bromine analyses of the halite samples confirm that the upper Z2 sulphate layer (Z2sl2) marks a freshening event in the Zechstein 2 Salt Member, which can be correlated throughout the entire in the study area. Although absolute Br-values are different, the general trends in Br-concentrations are similar in the two cores. This supports the use of $\mathrm{Br}$-concentration trends as correlation tool for re-freshening events in salt basins. The different absolute values are interpreted to reflect variable restrictions in different parts of the basin.

- Polyhalite is interpreted to have formed predominantly in palaeomorphologic lows. Areas that were elevated above brine level, like the Groningen High, were excluded from polyhalite precipitation. A further freshening of the brine led to the precipitation of gypsum on top of polyhalite in palaeo-structural lows, whereas palaeostructural highs like the Groningen High experienced only gypsum precipitation. During burial, gypsum was replaced by anhydrite.

- The external shape of salt structures does not necessarily reflect their internal deformation processes. With geophysical well logs, brittle intra-salt layers can be mapped on a regional scale and give information on the deformation processes, e.g. passive down-building or salt dissolution, which formed the present day salt structures. Subjacent salt dissolution was not the dominant process for salt-related deformation in the study area.

\section{Acknowledgements}

We would like to thank Rob de Wilde and Alex Klomp (TNO, Utrecht-Zeist) for kindly opening their core repository and the providing of core material, the Nederlandse Aardolie Maatschappije (NAM, Assen) for providing the digital data basis, Uwe Wollenberg (EMR RWTH) for the XRD measurements and the 
introduction to Rietveld analysis, Dennis Künkel (CIM RWTH) for performing the ion chromatography, Philipp Binger (EMR RWTH) for preparing the thin sections, as well as Theresa Stark (AMR RWTH) for providing the XRF-handheld equipment to us. We thank our reviewers Yuriy Maystrenko and Johannes Schoenherr for their comments and suggestions that highly improved the quality of our manuscript.

\section{References}

Adams AE, MacKenzie WS, Guilford C (1984) Atlas of sedimentary rocks under the microscope. Longman Group, Essex, UK.

Bäuerle G, Bornemann O, Mauthe F, Michalzik D (2000) Turbidites, breccias and grass-like crystal layers on the top of the Main Anhydrite (Zechstein 3) of the Gorleben salt dome. Zeitschrift der Deutschen Geologischen Gesellschaft 151 (1-2): 99-125

Behlau J, Mingerzahn G (2001) Geological and tectonic investigations in the former Morsleben salt mine (Germany) as a basis for the safety assessment of a radioactive waste repository. Engineering Geology 61: 8397. doi: 10.1016/s0013-7952(01)00038-2

Borchert H, Muir RO (1964) Salt deposits - the origin, metamorphism and deformation of evaporites. In: Fairbridge RW (ed) The University Series in Geology 338, D. van Norstrand Co. Ltd., London, 338 p.

Bornemann O, Behlau J, Fischbeck R, Hammer J, Jaritz W, Keller S, Mingerzahn G, Schramm M (2008) Description of the Gorleben site. - Pt.3: Results of the geological surface and underground exploration of the salt formation. Schweizerbart'sche Verlagsbuchhandlung, Stuttgart.

Braitsch O (1971) Salt deposits: their origin and composition. Springer Verlag, Berlin.

Brown A (1999) Interpretation of three-dimensional seismic data. Fifth edition. AAPG Memoir 42. The American Association of Petroleum Geologists and the Society of Exploration Geophysicists, Tulsa, USA.

Burchardt S, Koyi H, Schmeling H (2011) Strain pattern within and around denser blocks sinking within Newtonian salt structures. Journal of Structural Geology 33(2): 145-153. doi: 10.1016/j.jsg.2010.11.007

Burchardt S, Koyi, H, Schmeling H (2012) The influence of viscosity contrast on the strain pattern and magnitude within and around dense blocks sinking through Newtonian rock salt. Journal of Structural Geology 35: 102-116. doi: 10.1016/j.jsg.2011.07.007

Cartwright J, Steward S, Clark J (2001) Salt dissolution and salt-related deformation of the Forth Approaches Basin, UK North Sea. Marine and Petroleum Geology 18: 757-778.

Chemia Z, Koyi H, Schmeling H (2008) Numerical modelling of rise and fall of a dense layer in salt diapirs. Geophysical Journal International 172(2): 798-816. doi: 10.1111/j.1365-246X.2007.03661.x

Colter VS, Reed GE (1980) Zechstein 2 Fordon Evaporites of the Atwick No.1 borehole, surrounding areas of N.E. England and the adjacent southern North Sea. Contr. Sedimentology 9: 115-129.

de Jager J (2007) Geological development. In: Wong TE, Batjes DA, de Jager J (eds) Geology of the Netherlands, Royal Netherlands Academy of Arts and Science, Amsterdam, pp 5-26. 
Fiduk JC, Rowan MG (2012) Analysis of folding and deformation within layered evaporites in Blocks BM-S-8 \& -9, Santos Basin, Brazil. In: Alsop GI, Archer SG, Hartley AJ, Grant NT, Hodgkinson R (eds) Salt Tectonics, Sediments and Prospectivity, Geological Society Special Publications, London, pp 471-487.

Geluk MC, Paar WA, Fokker PA (2007) Salt. In: Wong TE, Batjes DA, de Jager J (eds) Geology of the Netherlands, Royal Netherlands Academy of Arts and Science, Amsterdam, pp. 283-294.

Geluk MC (1995) Stratigraphische Gliederung der Z2-(Staßfurt)-Salzfolge in den Niederlanden. Zeitschrift der Deutschen Geologischen Gesellschaft 146: 458-465.

Geluk MC (2000) Late Permian (Zechstein) carbonate-facies maps, the Netherlands. Geologie en Mijnbouw / Netherlands Journal of Geosciences 79(19): 17-27.

Geluk MC (2007) Permian. In: Wong TE, Batjes DA, de Jager J (eds) Geology of the Netherlands, Royal Netherlands Academy of Arts and Science, Amsterdam, pp 63-83.

Harvie CE, Weare JH, Hardie LA, Eugster HP (1980) Evaporation of seawater: calculated mineral sequences. Science 208: 498-500.

Ji S, Huang T, Fu K, Li Z (2011) Dirty salt velocity inversion: The road to a clearer subsalt image. Geophysics 76(5): WB169-WB174. doi: 10.1190/GEO2010-0392.1

Koyi HA (2001) Modeling the influence of sinking anhydrite blocks on salt diapirs targeted for hazardous waste disposal. Geology 29(5): 387-390. doi: 10.1130/0091-7613(2001)029 <0387:MTIOSA>2.0.CO;2

Kukla PA, Reuning L, Becker S, Urai JL, Schoenherr J (2011) Distribution and mechanisms of overpressure gernation and deflation in the late Neoproterozoic to early Cambrian South Oman Salt Basin. Geofluids 11(4): 349-361. doi: 10.1111/j.1468-8123.2011.00340.x

Kukla PA, Urai JL, Mohr M (2008) Dynamics of salt structures. In: Littke R, Bayer U, Gajewski D, Nelskamp S (eds) Dynamics of complex intracontinental basins: The Central European Basin System. Springer-Verlag, Berlin, pp 291-306.

Leveille JP, Jones IF, Zhou ZZ, Wang B, Liu F (2011) Subsalt imaging for exploration, production, and development: A review. Geophysics 76(5): WB3-WB20. doi: 10.1190/geo2011-0156.1

Li S, Abe S, Reuning L, Becker S, Urai JL, Kukla PA (2012a) Numerical modelling of the displacement and deformation of embedded rock bodies during salt tectonics: A case study from the South Oman Salt Basin. In: Alsop GI, Archer SG, Hartley AJ, Grant NT, Hodgkinson R (eds) Salt Tectonics, Sediments and Prospectivity. Geological Society, London, Special Publications 363: 503-520. doi: 10.1144/SP363.24

Li S, Abe S, Urai JL, Strozyk F, Kukla PA, van Gent H (2012b) A method to evaluate long-term rheology of Zechstein salt in Tertiary. In: Berest, Ghoreychi, Hadj-Hassen, Tijani (eds) Mechanical Behaviour of Salt VII, Taylor \& Francis Group, London, pp 215-220. doi: 10.1201/b12041-31

Logan BW (1987) The MacLeod evaporite basin, western Australia: Holocene environments, sediments and geological evolution. Tulsa OK, AAPG Memoir 44, 140 pp.

Mohr M, Kukla PA, Urai JL, Bresser G (2005) Multiphase salt tectonic evolution in NW Germany: seismic interpretation and retrodeformation. International Journal of Earth Sciences 94: 917-941. doi: 10.1007/s00531005-0039-5

Peryt TM, Tomassi-Morawiec H, Czapowski G, Hryniv SP, Pueyo JJ, Eastoe CJ, Vovnyuk S (2005) Polyhalite occurrence in the Werra (Zechstein, Upper Permian) Peribaltic Basin of Poland and Russia: Evaporite Facies Constraints. Carbonates and Evaporites 20(2): 182-194. doi: 10.1007/BF03175461 
Peryt TM, Geluk MC, Mathiesen A, Paul J, Smith K (2010) Zechstein. In: Doornenbal JC, Stevenson AG (eds) Petroleum Geological Atlas of the Southern Permian Basin Area, EAGE Publications b.v., Houten, pp 123-147.

Pharaoh TC, Dusar M, Geluk MC, Kockel F, Krawczyk CM, Krzywiec P, Schenk-Wenderoth M, Thybo H, Vejbæk OV, van Wees JD (2010) Tectonic Evolution. In: Doornenbal JC, Stevenson AG (eds) Petroleum Geological Atlas of the Southern Permian Basin Area, EAGE Publications b.v., Houten, pp 25-57.

Reuning L, Schoenherr J, Heimann A, Urai JL, Littke R, Kukla PA, Rawahi Z (2009) Constraints on the diagenesis, stratigraphy and internal dynamics of the surface piercing salt domes in the Ghaba Salt Basin (Oman): A comparison to the Ara formation in the South Oman Salt Basin. GeoArabia 14(3): 83-120.

RGD - Rijks Geologische Dienst (1991) - Geological Atlas of the Subsurface of The Netherlands, Explanantion to map sheet I Vlieland-Terschelling. Geological Survey of the Netherlands, Haarlem, 79 pp.

Rider M, Kennedy M (2011) The geological interpretation of well logs, 3rd edition, Rider-French Consulting Ltd, Sutherland, Scotland

Schoenherr J, Reuning L, Kukla PA, Littke R, Urai JL, Siemann M, Rawahi Z (2009) Halite cementation and carbonate diagenesis of intra-salt carbonate reservoirs of the Late Neoproterozoic to Early Cambrian Ara Group (South Oman Salt Basin). Sedimentology 56(2): 567-589. doi: 10.1111/j.1365-3091.2008.00986.x

Steward FH (1963) The Permian Lower Evaporites of Fordon in Yorkshire. Proceedings of the Yorkshire Geological Society 34: 1-44. doi:10.1144/pygs.34.1.1

Strozyk F, van Gent H, Urai JL, Kukla PA (2012) 3D seismic study of complex intra-salt deformation: an example from the Zechstein 3 stringer in the western Dutch offshore. In: Alsop GI, Archer SG, Hartley AJ, Grant NT, Hodgkinson R (eds) Salt Tectonics, Sediments and Prospectivity. Geological Society, London, Special Publications 363: 489-501. doi: 10.1144/SP363.23

Taylor JC (1998) Upper Permian - Zechstein. In: Glennie KW (ed) Petroleum Geology of the North Sea. Basic Concepts and Recent Advances, 4th ed, Blackwell Science, Oxford, pp 174-211. doi: 10.1002/9781444313413.ch6

van Adrichem Boogaert HA, Burgers WF (1983) The development of the Zechstein in the Netherlands. In: Kaasschieter JP, Reijers TJ (eds) Petroleum Geology of the southeastern North Sea and the adjacent onshore areas, Geologie en Mijnbouw 62: 83-92. doi: 10.1007/978-94-009-5532-5_8

van Gent H, Urai JL, de Keijzer M (2011) The internal geometry of salt structures - A first look using 3D seismic data from the Zechstein of the Netherlands. Journal of Structural Geology 33 (3): 292-311. doi: 10.1016/j.jsg2010.07.005

Vigh D, Kapoor J, Moldoveanu N, Li H (2011) Breakthrough acquisition and technologies for subsalt imaging. Geophysics 76(5): WB41-WB51. doi:10.1190/geo2010-0399.1

Wang B, Kim Y, Mason C, Zeng X (2008) Advances in velocity model-building technology for subsalt imaging. Geophysics 73(5): VE173-VE181. doi: 10.1190/1.2966096

Warren JK (2006) Evaporites: Sediments, Resources and Hydrocarbons. Springer Verlag, Berlin.

Warren JK (1982) Hydrologic setting, occurrence, and significance of gypsum in late Quarternary salt lakes, South Australia. Sedimentology 29(5): 609-637. doi: 10.1111/j.1365-3091.1982.tb00071.x

Weinberg RF (1993) The Upward Transport of Inclusions in Newtonian and Power-Law Salt Diapirs. Tectonophysics 228 (3-4): 141-150. doi: 10.1016/0040-1951(93)90337-J 
Williamson MD, Murray SJ, Atkins WS, Hamilton TAP, Copland MA (1997) A review of Zechstein drilling issues. SPE Drilling and Completion 13(3): 174-181. doi: 10.2118/38483-MS

Zulauf G, Zulauf J, Bornemann O, Kihm N, Peinl M, Zanella F (2009) Experimental deformation of a singlelayer anhydrite in halite matrix under bulk contriction. Part 1: geometric and kinematic aspects. Journal of Structural Geology 31(4): 460-474. doi: 10.1016/j.jsg.2009.01.013

\begin{tabular}{|c|c|c|c|c|c|c|c|c|c|c|c|}
\hline & \multirow{2}{*}{ Sample } & \multicolumn{5}{|c|}{ Sample Composition - Mineral Phase (\%) } & \multirow{2}{*}{ Depth } & \multicolumn{3}{|c|}{$\begin{array}{l}\text { Ion Chromatography } \\
(\mathrm{ppm})\end{array}$} & \multirow{2}{*}{ Lithology } \\
\hline & & Halite & Anhydrite & Polyhalite & Dolomite & Magnesite & & $\mathrm{Br}$ & Mg & Ca & \\
\hline \multirow{13}{*}{ 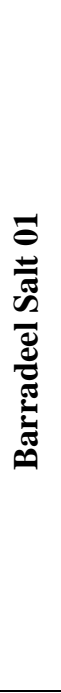 } & BAS-01A & 98.8 & 1.2 & - & - & - & 2676.1 & 306 & 264 & 411 & Z2 Salt \\
\hline & BAS-01B & 99.8 & 0.2 & - & - & - & 2676.7 & 307 & 614 & 388 & Z2 Salt \\
\hline & BAS-01C & 99.7 & 0.3 & - & - & - & 2676.8 & 288 & 193 & 361 & Z2 Salt \\
\hline & BAS-01D & 99.2 & 0.8 & - & - & - & 2676.9 & 310 & 498 & 356 & Z2 Salt \\
\hline & BAS-01E & 99 & 1 & - & - & - & 2677 & 310 & 425 & 365 & Z2 Salt \\
\hline & BAS-01F & - & 100 & - & - & - & 2677.05 & - & - & - & Z2sl2 \\
\hline & BAS-01G & - & 100 & - & - & - & 2677.15 & - & - & - & Z2sl2 \\
\hline & BAS-01H & - & 0.3 & 99.7 & - & - & 2677.53 & - & - & - & Z2sl2 \\
\hline & BAS-01I & - & - & 100 & - & - & 2677.62 & - & - & - & Z2sl2 \\
\hline & BAS-01K & 78.6 & - & 18.7 & 2.7 & - & 2678.1 & 359 & 8279 & 17550 & Z2 Salt \\
\hline & BAS-01L & 77.3 & - & 20.6 & 2.1 & - & 2678.37 & 341 & 8503 & 18108 & Z2 Salt \\
\hline & BAS-01M & 86.7 & - & 11.4 & 1.9 & - & 2678.62 & 377 & 5838 & 12521 & Z2 Salt \\
\hline & BAS-01N & 86.7 & - & 11.5 & 1.8 & - & 2679.6 & 381 & 6927 & 14660 & Z2 Salt \\
\hline \multirow{11}{*}{ 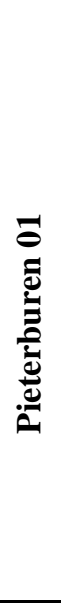 } & PBN-01C & 99.5 & 0.5 & - & - & - & 834.41 & 191 & 216 & 1560 & Z2 Salt \\
\hline & PBN-01D & 100 & - & - & - & - & 834.69 & 150 & 137 & 651 & Z2 Salt \\
\hline & PBN-01E & 99.3 & 0.7 & - & - & - & 834.79 & 136 & 38 & 456 & Z2 Salt \\
\hline & PBN-01F & 100 & - & - & - & - & 834.88 & 180 & 504 & 2720 & Z2 Salt \\
\hline & PBN-01G & 100 & - & - & - & - & 835 & 130 & 49 & 690 & Z2 Salt \\
\hline & PBN-01H & 7.1 & 92.9 & - & - & - & 835.01 & - & - & - & Z2sl2 \\
\hline & PBN-01I & 99.6 & 0.4 & - & - & - & 835.34 & 130 & 54 & 492 & Z2 Salt \\
\hline & PBN-01K & 99.3 & 0.7 & - & - & - & 835.44 & 169 & 305 & 3303 & Z2 Salt \\
\hline & PBN-01M & 99 & 1 & - & - & - & 835.69 & 189 & 338 & 820 & Z2 Salt \\
\hline & PBN-01P & 0.9 & 95.1 & - & - & 4 & 835.1 & - & - & - & Z2sl2 \\
\hline & PBN-01Q & 0.6 & 87 & - & - & 12.4 & 835.2 & - & - & - & Z2sl2 \\
\hline
\end{tabular}

Table 1 Mineral phases quantified by Rietveld analysis (left) and results of ion chromatography (IC; right). The internal precession of the IC measurements ranges between $0.8 \%$ and $1.3 \%$ ( 1 standard deviation; 1SD). The calculated error for the Rietveld analysis is less than $\pm 1.5 \%$. 


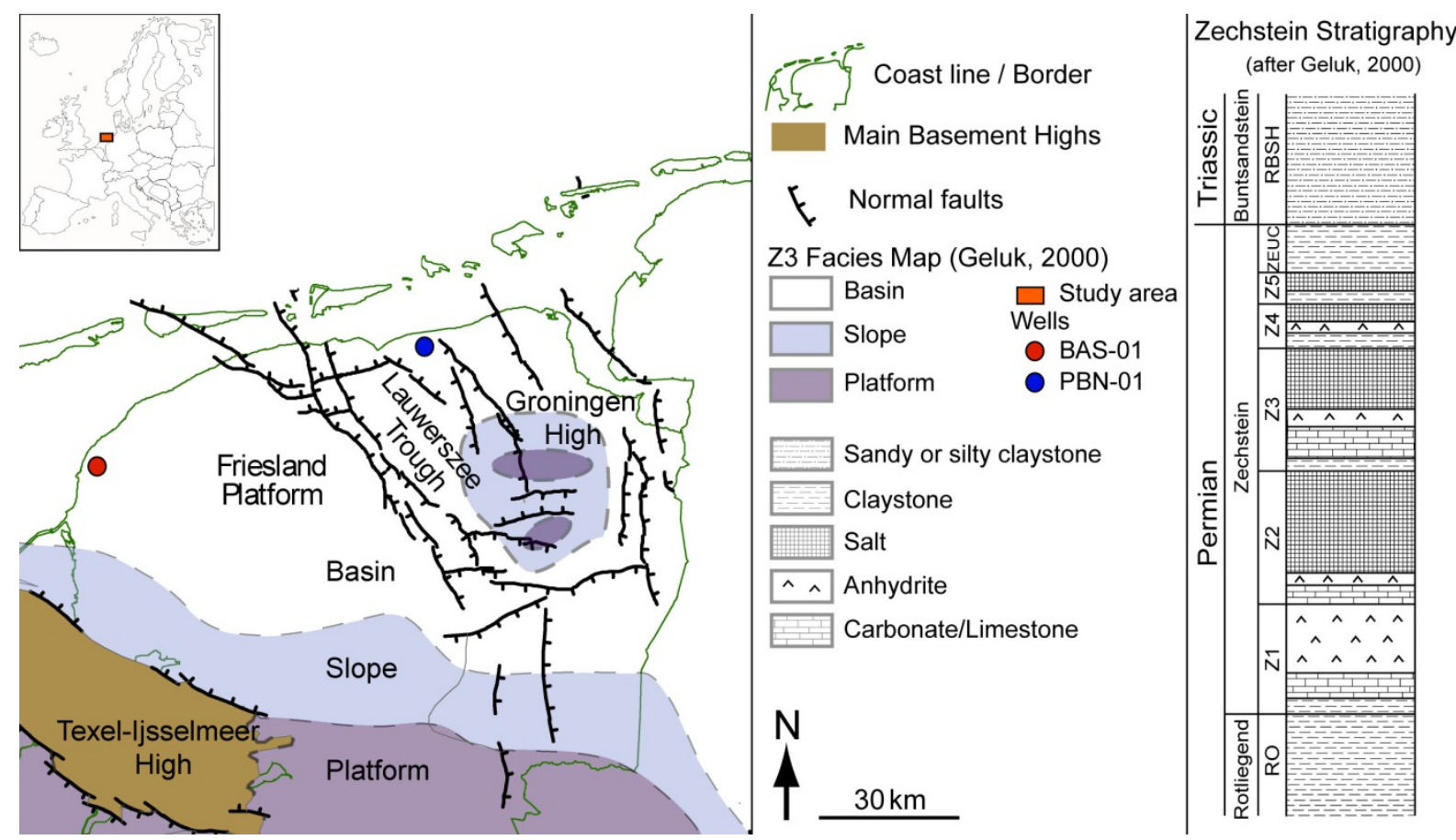

Fig. 1 Location of wells BAS-01 and PBN-01 with today's structural elements (image courtesy of Nederlandse Aardolie Maatschappij) and Z3 palaeogeography (after Geluk, 2000) onshore the northern Netherlands (modified from de Jager 2007 and van Gent et al. 2011)
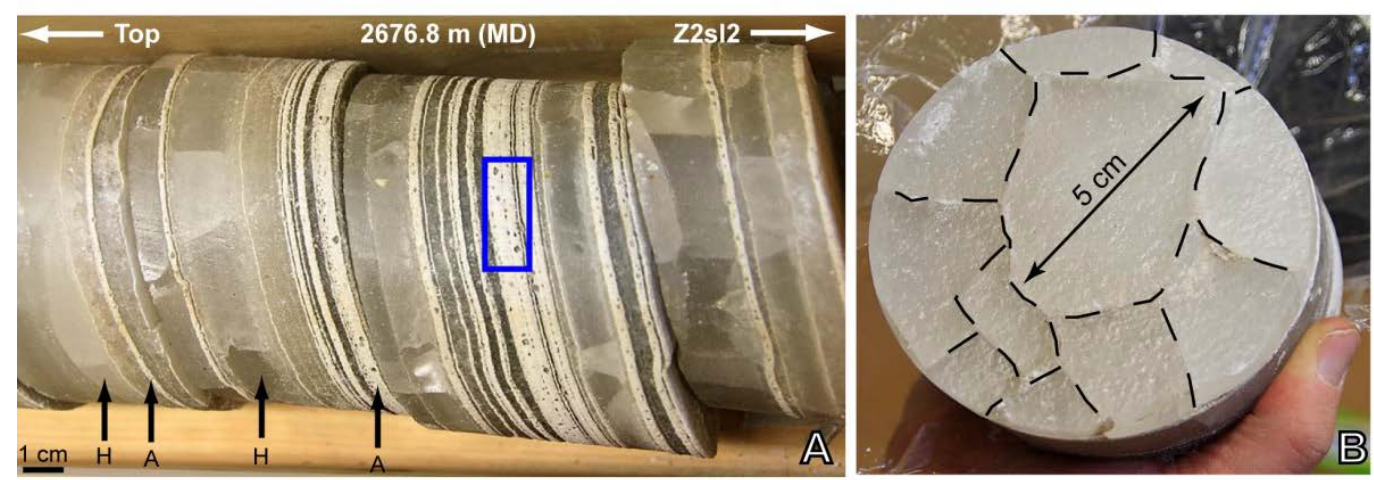

Fig 2 Photographs of Zechstein 2 Salt Member of well BAS-01

A - Intercalation of thin anhydrite (A) layers within salt above Z2sl2. The thickness of the individual halite $(\mathrm{H})$ layers varies from $1-10 \mathrm{~cm}$. Small, euhedral halite crystals are present inside anhydrite layers (rectangle)

B - Halite layers above Z2sl2 show halite crystals with very large crystal sizes of up to $5 \mathrm{~cm}$ in diameter. The crystal boundaries are indicated by the dashed line 

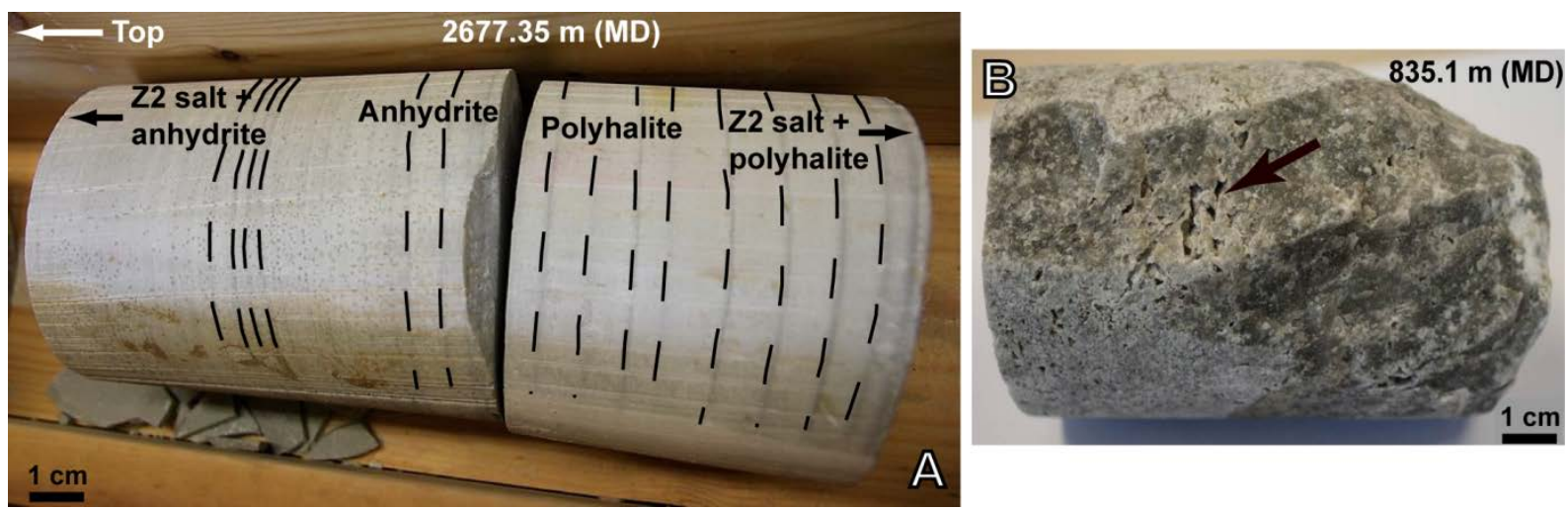

Fig. 3 Photographs of Z2sl2

A - The light grey Z2sl2 layer of well BAS-01 consists of an anhydrite layer (top interval) and a polyhalite layer (bottom interval). The Z2sl2 layer consists of a light grey, massive to partly laminated material. The dark laminae have a thickness less than $2 \mathrm{~mm}$ and decrease in abundance with depth, where they occur in intervals of 1 - $2 \mathrm{~cm}$. In contrast, the top of the Z2sl2 layer shows lamination intervals $<5 \mathrm{~mm}$

B - The Z2sl2 layer of well PBN-01 consists of dark grey, massive anhydrite. The abundant open porosity (arrow) was likely plugged with halite in the sub-surface 


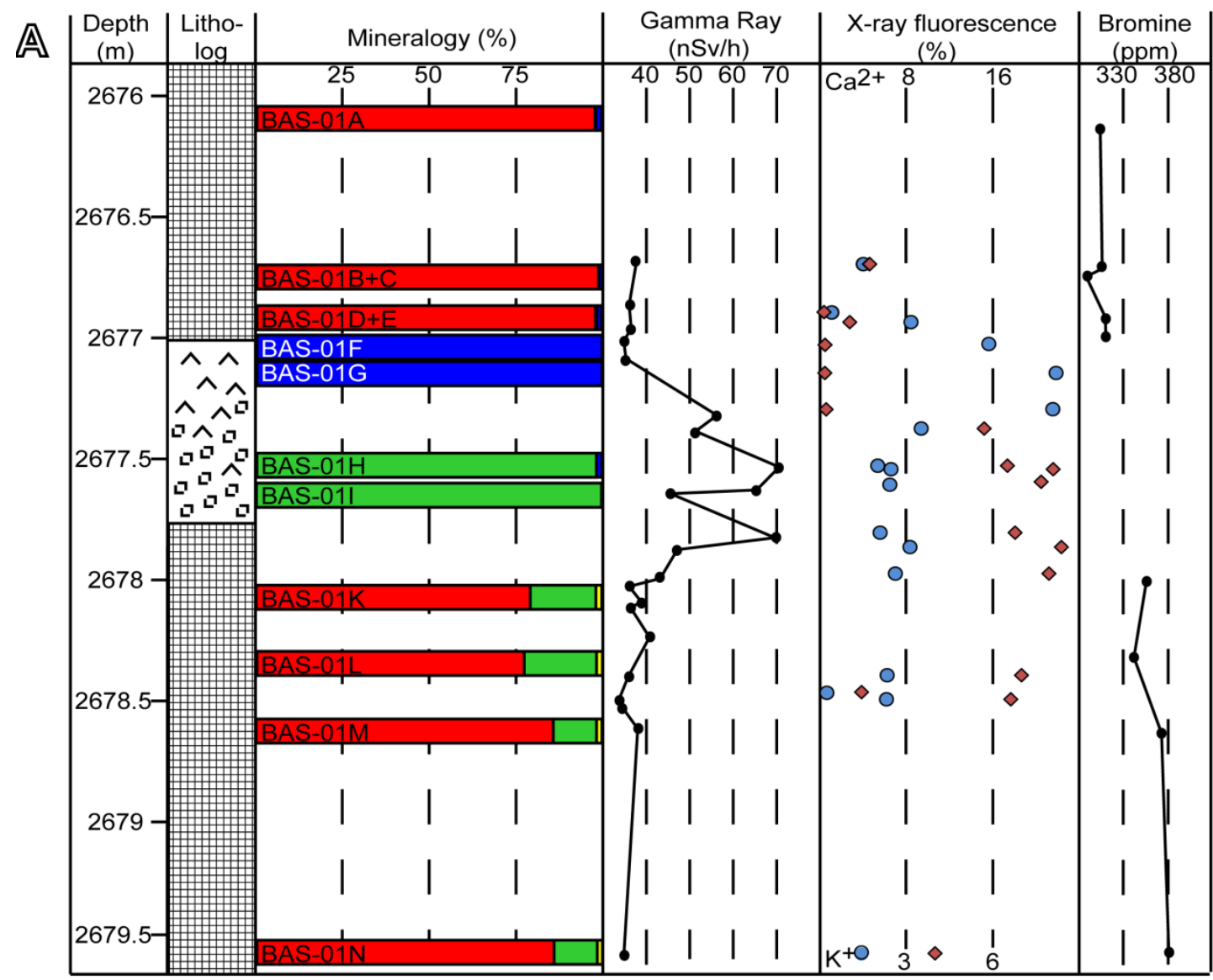

回

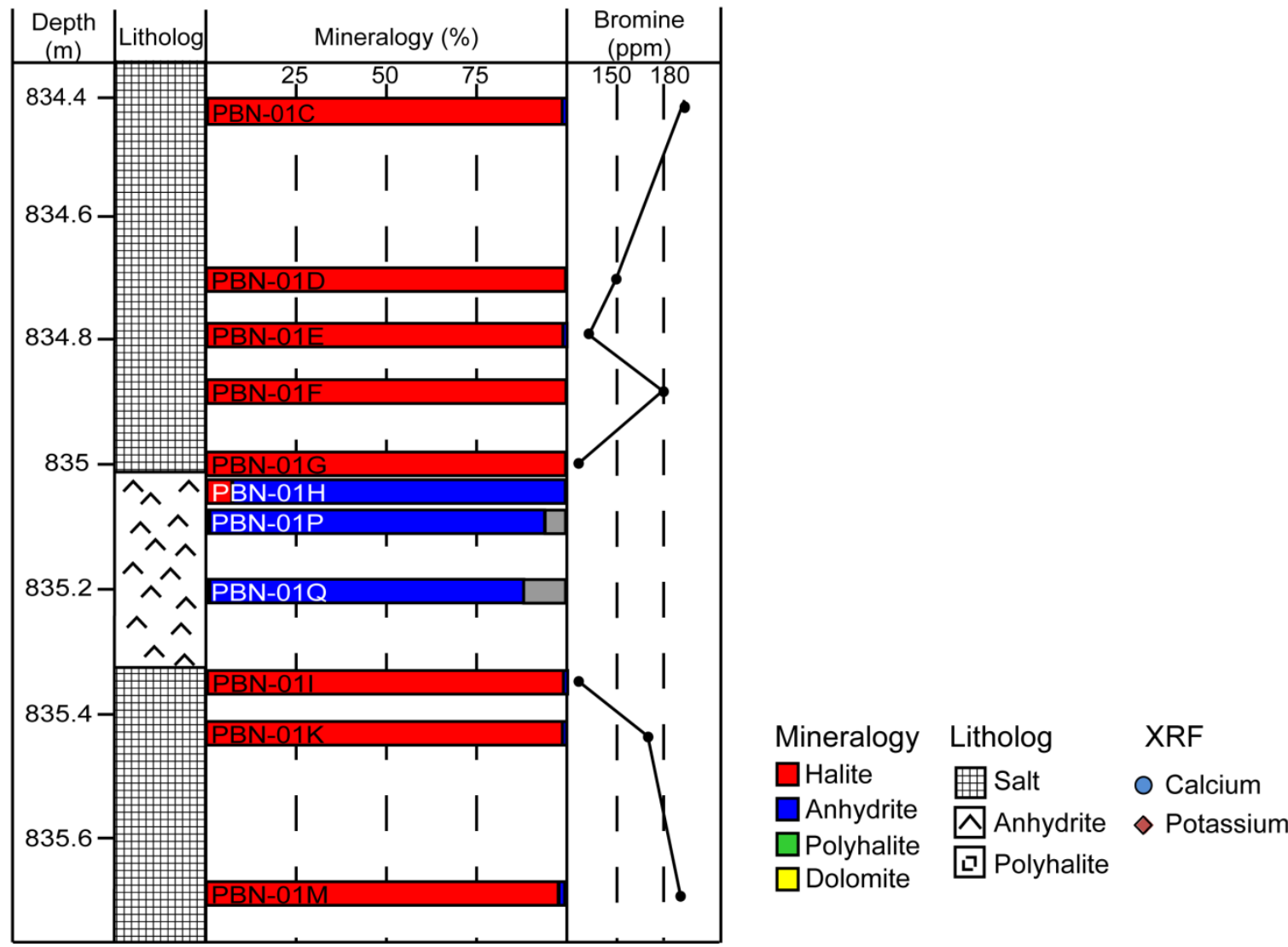

Fig. 4 Results of XRD and ion chromatography measurements (A: BAS-01; B:PBN-01), as well as the results of gamma ray and XRF (A: BAS-01) for the Zechstein 2 Salt Member samples. The internal precession (1SD) of the XRF results is $\pm 0.4 \%$ for calcium and $\pm 1 \%$ for potassium 

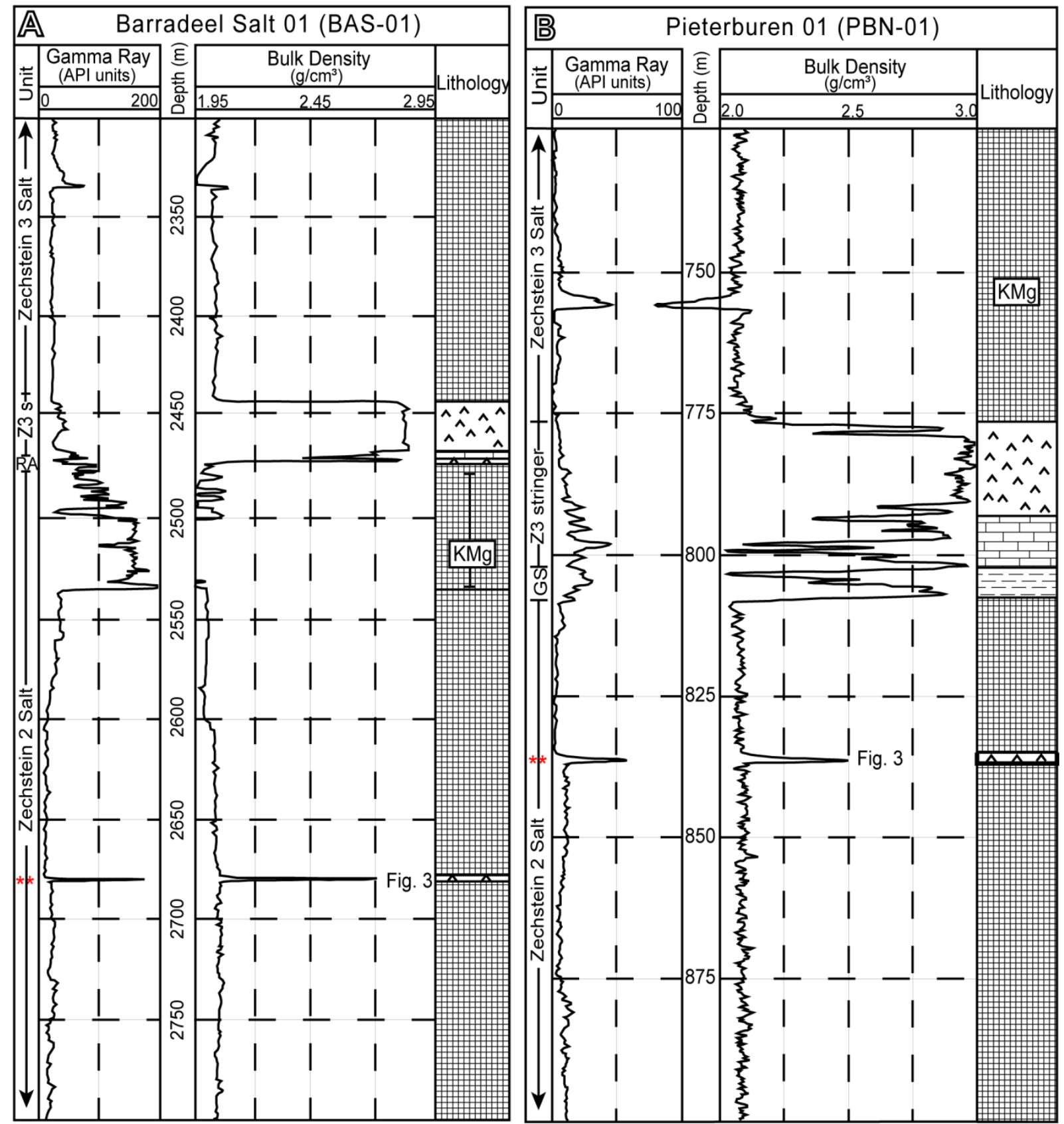

Fig. 5 Gamma ray and density logs of wells BAS-01 (A) and PBN-01(B) for the Zechstein 2 Salt to Zechstein 3 Salt Member. The Z2sl2 layer is marked by high gamma ray and density values in $2677 \mathrm{~m}$ depth (A) and $835 \mathrm{~m}$ depth (B). K-Mg-salts occur between $2500 \mathrm{~m}$ and $2540 \mathrm{~m}$ depth (A; Z2 Salt) and in $755 \mathrm{~m}$ depth (B; Z3 Salt). $\mathrm{RA}=$ Roof Anhydrite, GS = Grey Salt Clay with high anhydrite content, Z3 s = Z3 stringer, ** = Z2sl2 


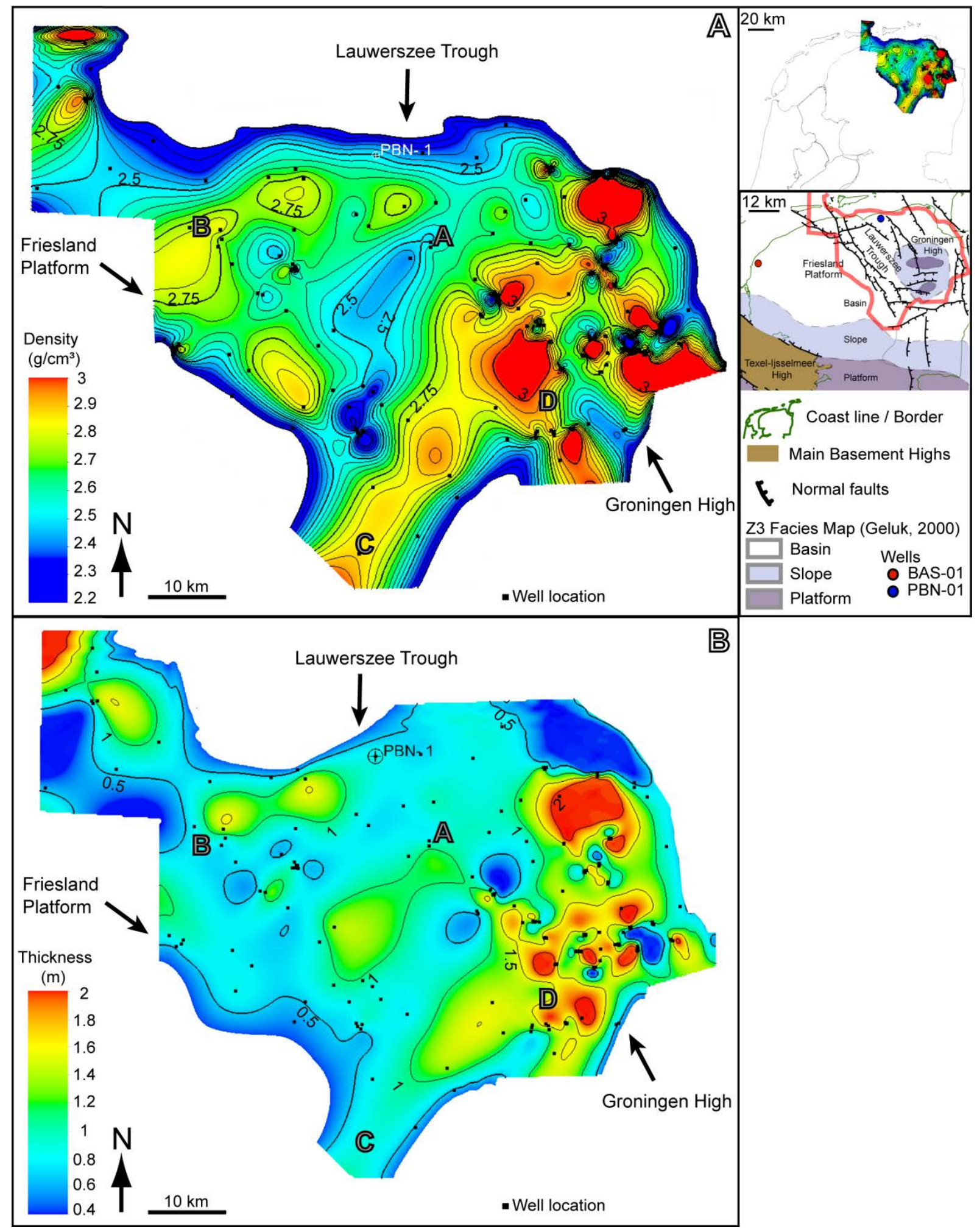

Fig. 6 Geophysical log based density and thickness maps of the Z2sl2 layer onshore the northern Netherlands A - Ma of maximum Z2sl2 densities. Density annotations are given on bold lines. The highest density values (red) are found on and around the Groningen High, whereas lower densities are present basin-wards in the area of the Lauwerszee Trough and the north-western coastal area. The locations of wells used for this map are indicated by black rectangles and wells A-D were used for Fig. 7

B - Thickness map of the Z2sl2 layer onshore the northern Netherlands. The map indicates that the maximum Z2sl2 thickness ( $2 \mathrm{~m}$ ) is found on and around the Groningen High. Minor thicknesses (>0.5 m) are found in the area of the Lauwerszee Trough 


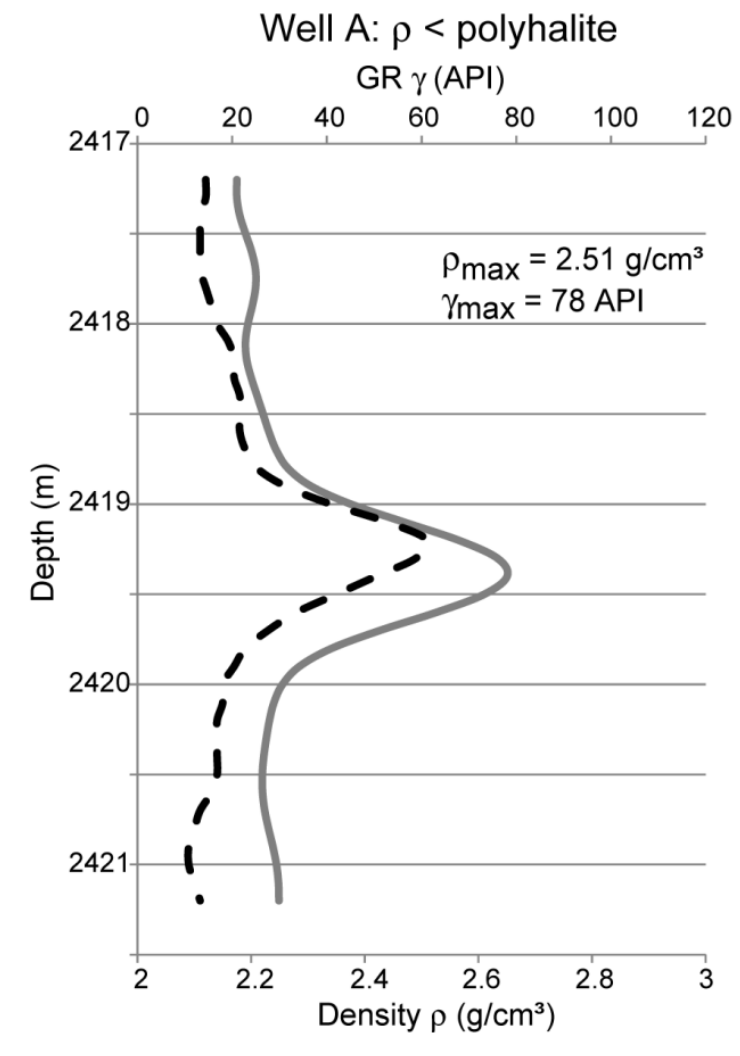

Well C: polyhalite $<\rho<$ anhydrite

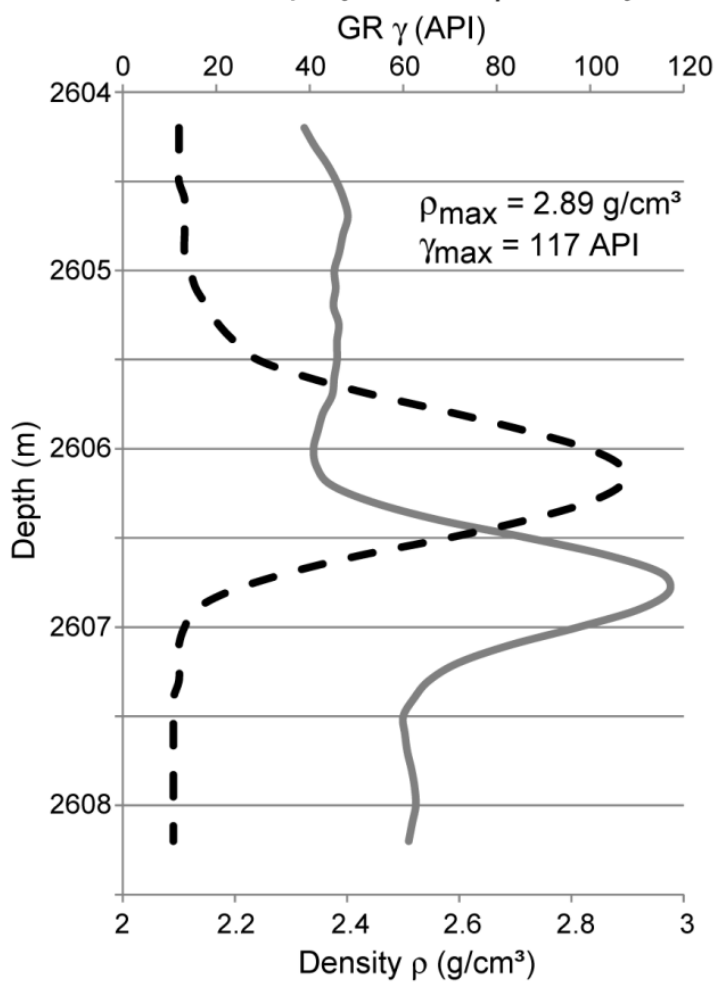

Well B: $\rho=$ polyhalite
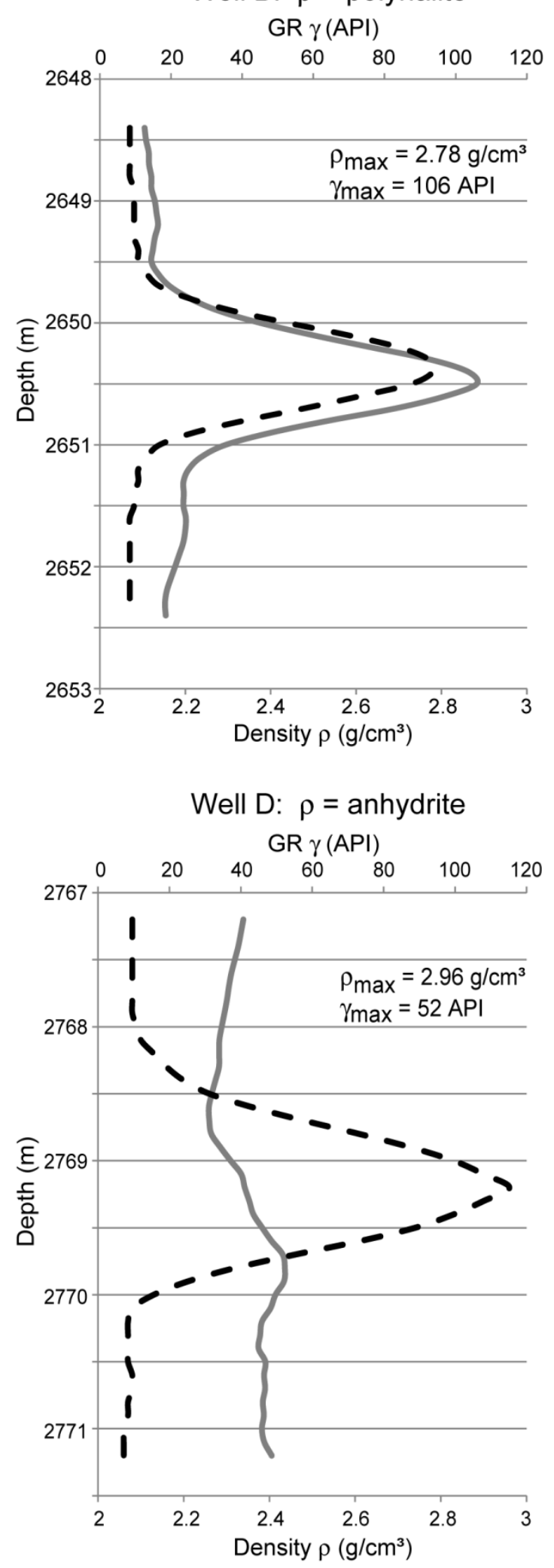

\section{- Density \\ Gamma Ray}

Fig. 7 Typical density (dashed line) and gamma ray log (continuous line) signatures that can be related to spatial changes in evaporite mineralogy within the Z2sl2 layer. Wells A and B: A density maximum $<2.8 \mathrm{~g} / \mathrm{cm}^{3}$, which is associated with a clear gamma-ray peak, points to a predominance of polyhalite. Well A shows density and gamma-ray peaks lower than typical polyhalite values, indicating that the Z2sl2 layer is probably thinner than the vertical resolution of the logging tool. Well C: The relatively large offset between the density and gamma-ray 
peaks indicates that anhydrite predominates at the base and polyhalite at the top of the layer. Well D: The lack of a gamma-ray peak in combination with a very high density maximum for the Z2sl2 layer indicates that anhydrite is the predominant mineral phase. Well D shows a signature that is typical for the Groningen High. Typical log values for the $\mathrm{Z} 2$ salt are a density of $2.1 \mathrm{~g} / \mathrm{cm}^{3}$ and a natural radioactivity of $<20$ API units
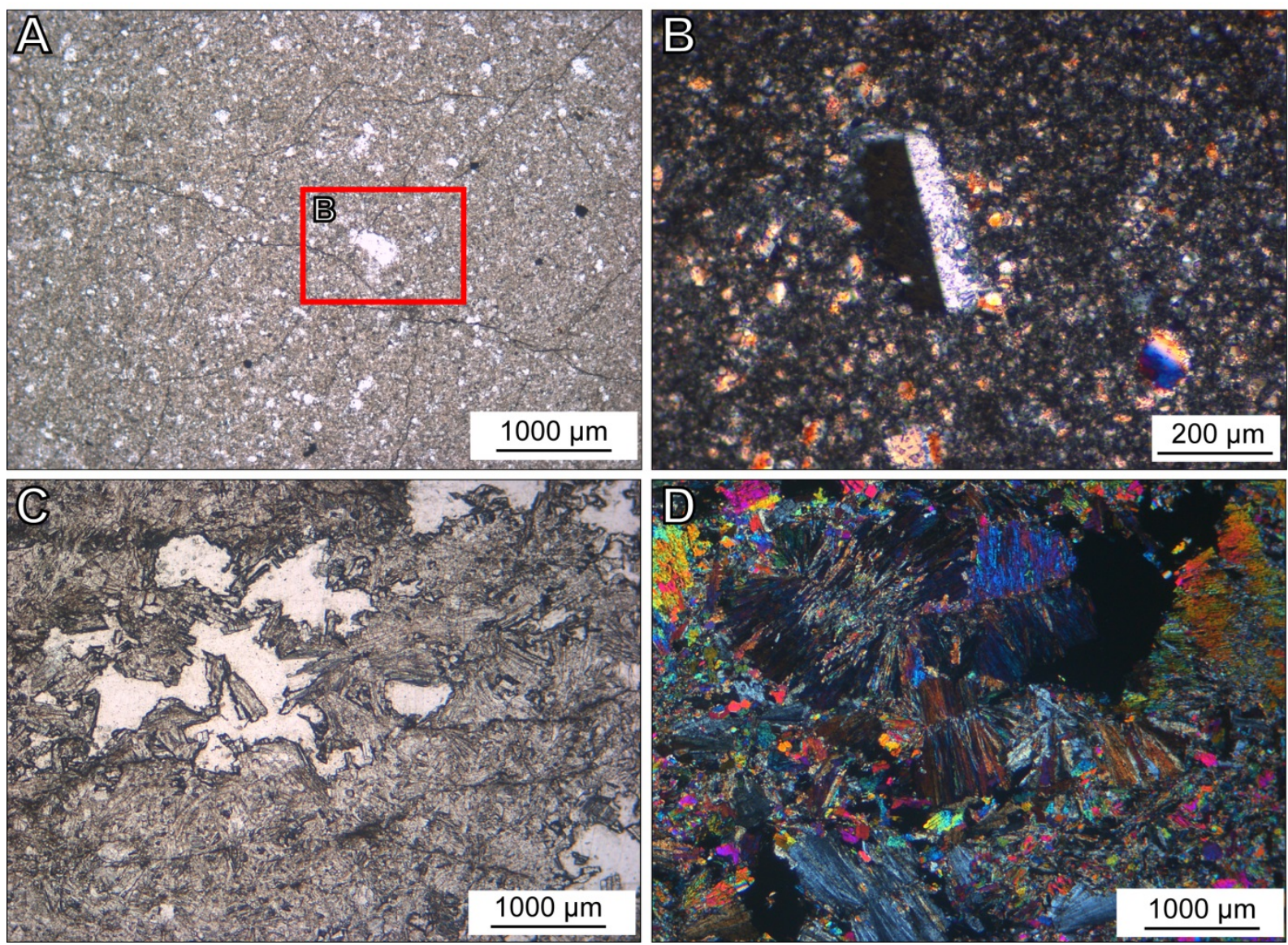

Fig. 8 Thin-section microscopy pictures of Z2sl2 layer

A - BAS-01. Isolated, coarser grained polyhalite crystals embedded in a fine-grained, greyish matrix of granular polyhalite. Dark patches are inclusions of organic matter or bitumen (plane polarized light, ppl)

B - Picture detail of A under crossed polarized light (xpl). The polyhalite crystals show low interference colours up to low second order and especially the coarser crystals show a distinctive simple twinning.

C - PBN-01. Radial- and felted-fibrous anhydrite (grey; ppl). Remnants of halite cement are visible inside vugs but most of the halite was apparently lost during thin-section preparation.

D - PBN-01. Anhydrite crystals are arranged in parallel to radial-fibrous aggregates (xpl) 


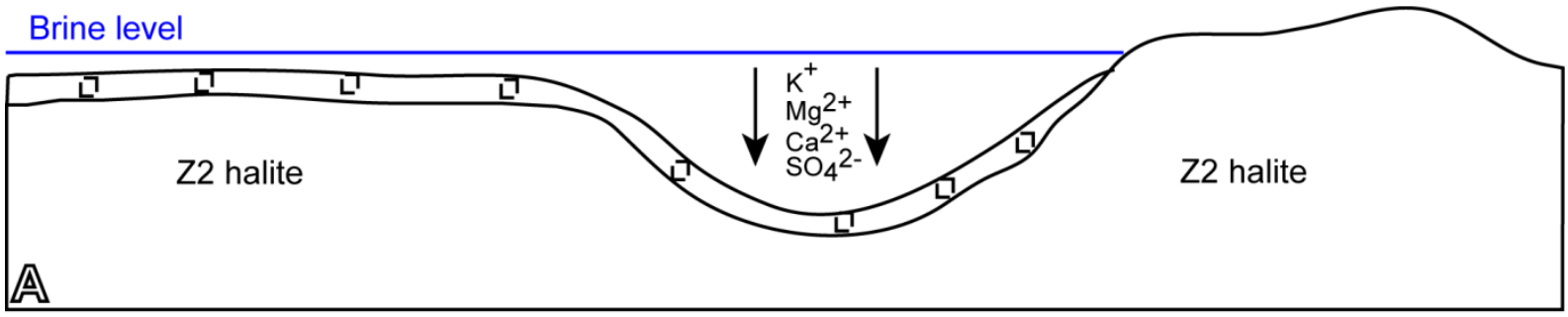

Friesland Platform

Lauwerszee Trough

Groningen High

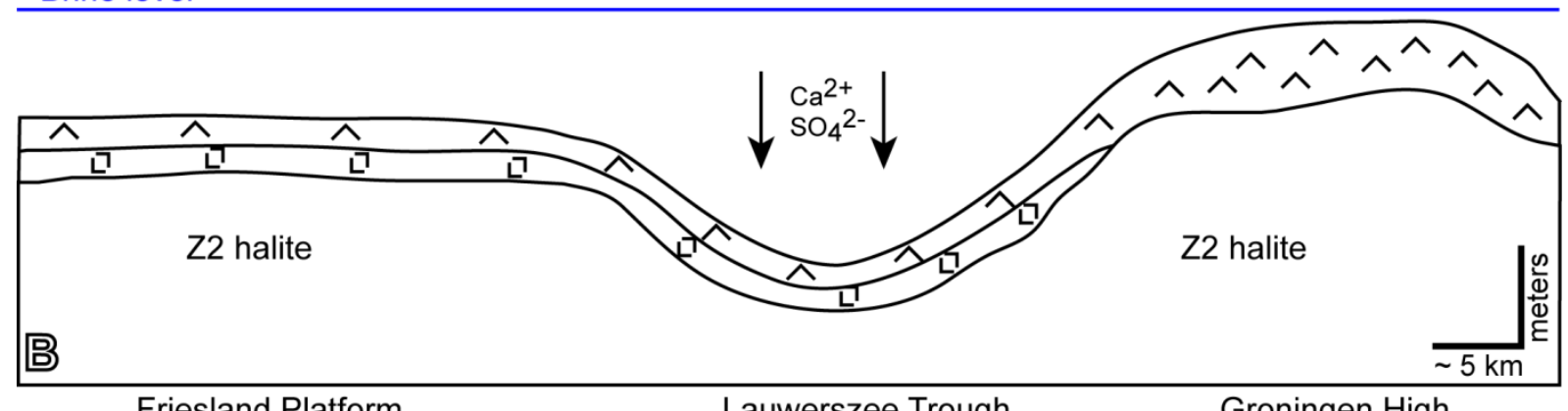

Friesland Platform

Lauwerszee Trough

Groningen High

Fig. 9 Conceptual model for the deposition of the Z2sl2 layer (relief meters to tens of meters scale)

A - Initial freshening leads to precipitation of polyhalite in morphologic lows on top of halite, while the Groningen High is elevated above brine level and free from polyhalite precipitation.

B - Continued freshening and rise of brine level: precipitation of anhydrite on top of polyhalite and first sulphate sedimentation in form of anhydrite or gypsum along the Groningen High. Note that maximum thicknesses of the Z2sl2 layer are present on structural highs 


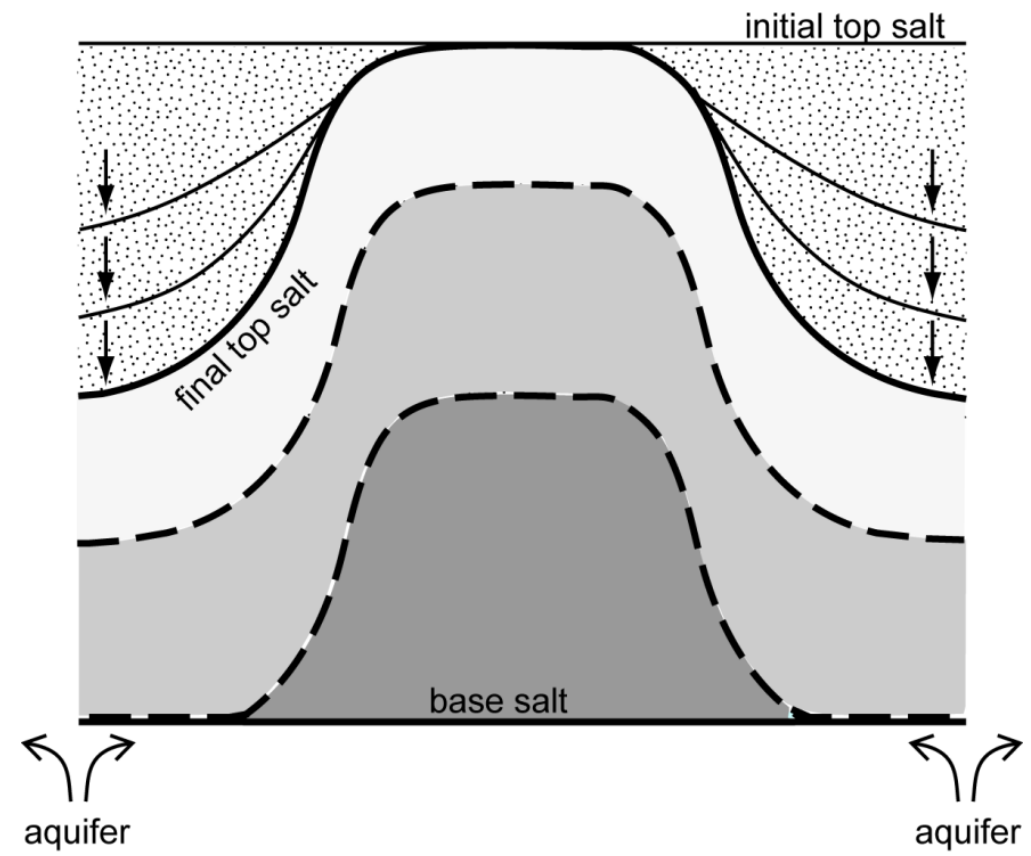

Fig. 10 Schematic section showing possible kinematic evolution of a salt body and the deformation of intra-salt layers (dashed lines) due to subjacent salt dissolution caused by focused flow of undersaturated waters along the base of the salt unit (modified from Cartwright et al. 2001). Curved arrows indicate direction of fluid flow, vertical arrows indicate direction of movement of the top salt surface relative to initial top salt. Where salt is removed by subjacent dissolution, the final top salt position is below its initial position. The accommodation space created by dissolution at the base of the salt unit is filled rapidly by sediments showing convergent onlap onto the flanks of the salt structure. The part of the salt unit that was not affected by dissolution now forms the crest of the salt structure with a top salt surface close to its original datum.

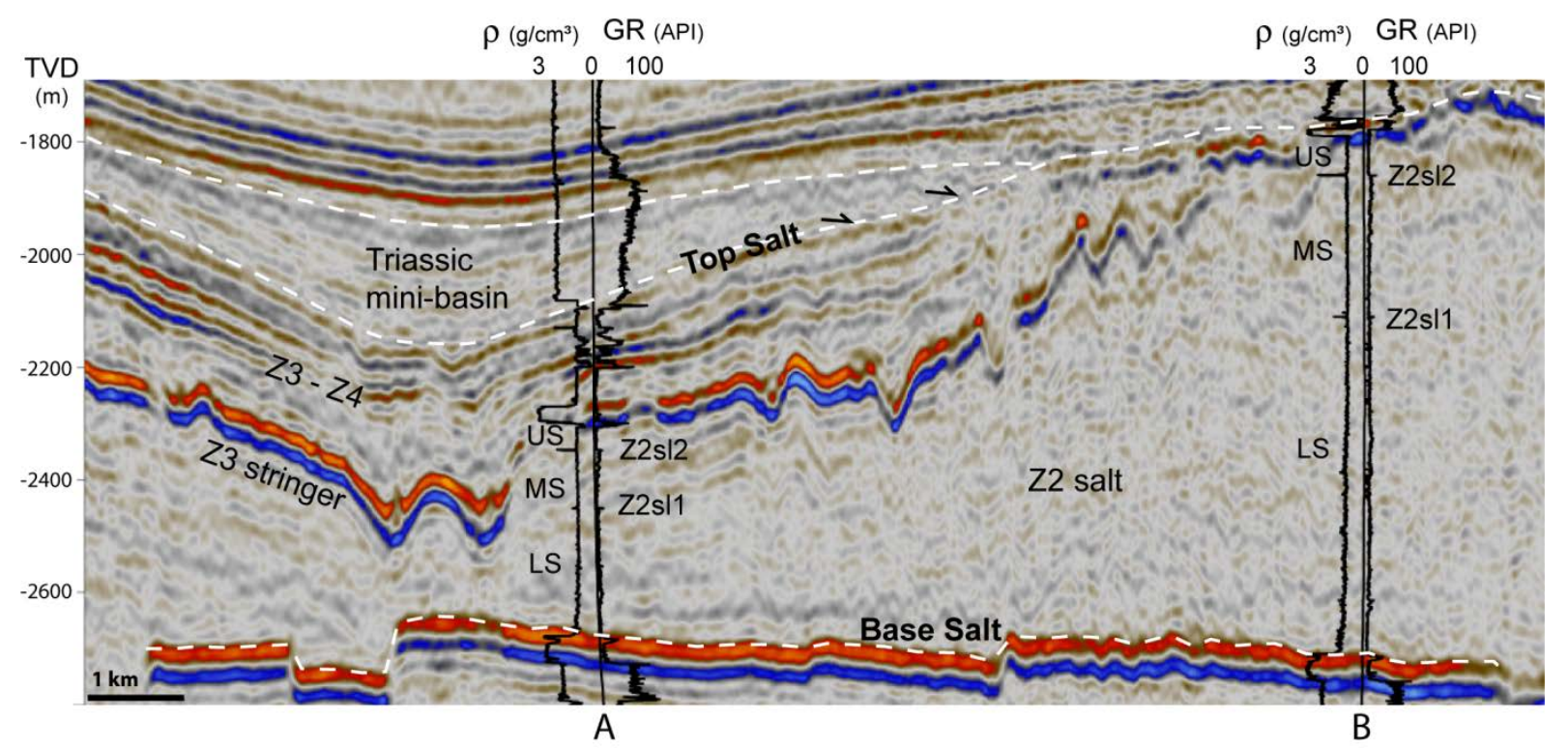

Fig. 11 Interpreted seismic section from the Groningen High (TVD; seismic data courtesy of NAM; vertical exaggerated: $\sim 5 \mathrm{x}$ ) showing high amplitude reflectors for the Z3 stringer and the Base Salt. The reflectors within the Triassic mini-basin show convergent onlap onto the flank of the salt structure (black arrows). Density logs (in $\mathrm{g} / \mathrm{cm}^{3}$ ) and gamma ray logs (in API units) of two wells (A, B) are given. The Z2 salt is divided in Lower Salt (LS), Middle Salt (MS), and Upper Salt (US) by two intra-salt sulphate layers (Z2sl1 and Z2sl2). At well A, the thickness of the total Z2 layer is reduced by $60 \%$ compared to well B. The Lower, Middle and Upper Salt units at well $\mathrm{A}$ are reduced by $63 \%, 60 \%$ and $45 \%$, respectively. 